www.jmscr.igmpublication.org

Impact Factor (SJIF): 6.379

Index Copernicus Value: 79.54

ISSN (e)-2347-176x ISSN (p) 2455-0450

crossrefDOI: https://dx.doi.org/10.18535/jmscr/v6i10.37

Journal Of Medical Science And Clinical Research

Research Article

\title{
Comparative Study to Assess the Level of Self- Esteem and Achievement Motivation among Adolescents in Rural and Urban Pre-University Colleges, Mangaluru
}

\author{
Authors \\ Dr Veena Gretta Tauro ${ }^{1}$, Vijetha Kottari ${ }^{2 *}$, Princia Rolita D'Souza ${ }^{3}$ \\ ${ }^{1}$ Principal, Masood College of Nursing, Mangaluru, Karnataka \\ Email:venatauro@hotmail.com \\ ${ }^{2}$ Head of Department of Pediatric Nursing, Masood College of Nursing, Mangaluru, Karnataka \\ ${ }^{3}$ MSc Nursing, Masood College of Nursing, Mangaluru, Karnataka \\ Email: princiabhishek28@gmail.com \\ *Corresponding Author \\ Vijetha Kottari \\ Email:vijethaky@gmail.com
}

\begin{abstract}
The study compared the level of self-esteem and achievement motivation among adolescents in rural and urban pre-university colleges, Mangalore. The research approach used for the study was descriptive and comparative approach. A comparative descriptive research design was used to study 240 adolescents from rural and urban preuniversity college, selected by multistage random sampling technique. The data was collected using Rosenberg Self-esteem and Achievement Motivation Scale. The data collected was analysed using descriptive and inferential statistics to achieve the objectives of the study and to test the research hypotheses. The results revealed that Majority (98.3\%) of adolescents in urban pre-university college had high level of self-esteem, whereas the adolescents of rural pre-university college, majority (86.7\%) had average level of self-esteem. Most (70\%) of the adolescents of urban pre-university college had high level of achievement motivation whereas $50 \%$ of them from rural pre-university college had above average level of achievement motivation. There was a significant difference in the level of self-esteem $(t=15.892, p<0.05)$ and level of achievement motivation $(t=16.498, p<0.05)$ of adolescents rural and urban pre-university college. There was significant association between level of self-esteem of rural and urban adolescents studying in pre-university college with streams of education of mother and percentage of marks in $10^{\text {th }}$ exam. There was significant association between the levels of achievement motivation among adolescents of rural pre-university college with streams of education. The study concluded that Parents and teachers should be encouraged and motivated to provide their children with a large amount of support in order to raise their children's self-esteem and achievement motivation and lessen the likelihood that their children will be prey to the antisocial behaviour.

Keywords: Self-esteem; achievement motivation; adolescents.
\end{abstract}

\section{Introduction}

Adolescent period is the second decade of life. It is a period of human development during which a person must move from dependency to the interdependency, autonomy, maturity and gradual transformation or metamorphosis of the person or child into a new person as an adult. ${ }^{1}$ Today's adolescents and youth are 1.8 billion strong and 
make up one quarter of the world's population. It is reported that $19 \%$ of the world's population is in the age of 10 to 19 years. India is the largest population of adolescents in the world being home to 243 million individuals aged 10 to 19 year. World's children's report stated that the country's adolescent population constituted 30\% of the world's 1.2 billion. In Dakshina Kannada, approximately 2,00,000 adolescents are there between the age group of 12 and 16 years. In Karnataka, the total population is 52.73 million and adolescent population constitutes $17 \%$ of the total population. ${ }^{2}$ Adolescence is a time of moving from the immaturity of childhood into the maturity of adulthood. Early adolescence is the stage in which self-esteem and academic achievement become the major part of life. Both are important to the development of their personality. ${ }^{3}$ Current scenario of adolescents clearly shows that condition of the youth has significantly deteriorated. Recent study have shown that there is significant rise in emotional disturbances, increased sexuality in schools, rise in AIDS cases and greater use of alcohol consumption, use of heavy drugs and youth drop outs have also increased. ${ }^{4}$ This multitude of psychological, physical, emotional and social problems to a certain extent is contributed by the low self-esteem in adolescents. ${ }^{5}$

Change is universal as is the change during adolescence period. Period of adolescence brings change in every sense - both biologically and psychosocially - which brings out a new individual. Some adolescents are able to move ahead because of factors like parenting, college environment, peer support and individual factors. Children have highest self-esteem when the parents are loving, supportive and deeply involved in their lives. ${ }^{6}$ Adolescents with low self-esteem tend to have a wide range of problems such as poor academic achievement, criminal and violent behaviour. ${ }^{7}$ Achievement motivation is also an important part of their life and can affect the adolescents in regards to self-esteem, conscience development, goals and its outcome. ${ }^{8}$ Hence, the investigator felt the need to conduct a study to assess the level of self-esteem and achievement motivation among rural and urban adolescents pre-university colleges.

\section{Statement of the problem}

"Comparative study to assess the level of selfesteem and achievement motivation among adolescents in selected rural and urban preuniversity colleges, Mangaluru."

\section{Objectives of the study}

The objectives of the study are:

- To assess the level of self-esteem among rural and urban pre-university college adolescents.

- To assess the level of achievement motivation among rural and urban preuniversity college adolescents.

- To compare the level of self-esteem between rural and urban pre-university college adolescents.

- To compare the level of achievement motivation between rural and urban preuniversity college adolescents.

- To find out the association between the level of self-esteem between rural and urban pre-university college adolescents with selected demographic variables.

- To find out the association between levels of achievement motivation between rural and urban pre-university college adolescents with selected demographic variables.

\section{Hypotheses}

The hypotheses will be tested at 0.05 level of significance

$\mathrm{H}_{1}$ : There is significant difference in level of selfesteem among adolescents studying in rural and urban pre-university colleges.

$\mathrm{H}_{2}$ : There is significant difference in level of achievement motivation among adolescents studying in rural and urban pre-university colleges. 
$\mathrm{H}_{3}$ : There is significant association between level of self-esteem among adolescents studying in rural and urban pre-university college with their selected demographic variables.

$\mathrm{H}_{4}$ : There is a association between level of achievement motivation among adolescents studying in rural and urban pre-university college with their selected demographic variables.

\section{Methodology}

The research approach used for the study was descriptive and comparative approach. A comparative descriptive research design was used to study 240 adolescents of age 16 to 18 years from rural and urban pre-university college. Rural and urban colleges for the study were selected by purposive sampling technique. The data was collected using Rosenberg Self-esteem and Achievement Motivation Scale by VP Bharghav.

Self esteem scale was developed by Dr. Rosenberg in 1975. Ten statements are included in the self report measure that pertains to self worth and self acceptance. A four point scale ranging from "Strongly Agree"(SA) to "Strongly Disagree (SD). In that 5 items were positive and 5 items were negative. The positive statements had scoring 3,2,1, 0 whereas the negative statements had $0,1,2,3$; the items are summed up to obtain a total score that can range from 0 to 30 . The scale presented high rating in reliability areas; reliability: internal consistency was 0.77 ; minimum coefficient of reproducibility was 0.90 . Test retest reliability for the two week interval was calculated at 0.85 , the month interval was calculated at 0.63 .

Achievement Motive Test was developed by VP Bharghav. The present tool consisted of 50 items of incomplete sentences or items which are to be completed by putting a check mark on any one of the three alternative responses given against each item. The person is instructed about what they have to do and are required to check the item by choosing one of the alternative responses which indicate his true feelings with respect to the point asked through a particular item. The reliability of coefficient was 0.91 and test retest reliability was calculated at 0.79 .

The Pilot study was conducted and results concluded that there was significant difference in the level of self-esteem and achievement motivation among adolescents of rural and urban pre-university colleges. The research tools were found to be feasible and practicable. No further changes were done in the tool after the pilot study. Ethical clearance was obtained from ethical committee. A written informed consent was obtained from the participants. The data collected was analysed using descriptive and inferential statistics to achieve the objectives of the study and to test the research hypotheses.

\section{Results}

The results revealed the following findings

Table 1: Frequency and percentage distribution of demographic variables as per age, religion, gender, residential area, type of family, birth order and income of the adolescents family.

\begin{tabular}{|c|c|c|c|c|c|}
\hline \multirow[b]{3}{*}{$\begin{array}{l}\text { Sl. } \\
\text { No. }\end{array}$} & \multirow[b]{3}{*}{ Demographic variables } & \multirow{3}{*}{$\begin{array}{r}\text { Rural } \\
\text { Frequency } \\
\text { (f) }\end{array}$} & \multirow{2}{*}{\multicolumn{3}{|c|}{ Urban }} \\
\hline & & & & & \\
\hline & & & $\begin{array}{l}\text { Percentage } \\
(\%)\end{array}$ & $\begin{array}{l}\text { Frequency } \\
\text { (f) }\end{array}$ & $\begin{array}{l}\text { Percentage } \\
(\%)\end{array}$ \\
\hline \multirow[t]{4}{*}{1.} & Age in years & & & & \\
\hline & a. 16 & 87 & 72.5 & 87 & 72.5 \\
\hline & b. 17 & 33 & 27.5 & 33 & 27.5 \\
\hline & c. 18 & 0 & 0.00 & 0 & 0.00 \\
\hline \multirow[t]{4}{*}{2.} & Religion & & & & \\
\hline & a. Hindu & 69 & 57.5 & 42 & 35.0 \\
\hline & b. Muslim & 26 & 21.7 & 24 & 20.0 \\
\hline & c. Christian & 25 & 20.8 & 54 & 45.0 \\
\hline
\end{tabular}


3. Gender
a. Male
b. Female

4. Residential area
a. Rural
b. Urban

5. Type of family
a. Nuclear
b. Joint family
c. Extended family
d. Single parent family

6. Order of birth
a. First
b. Second
c. Third and above

7. Monthly income of the family
a. Up to 5000
b. $5001-10,000$
c. $10,000-15,000$
d. More than 15,000

66

54

55.0

45.0

85.8

14.2

34.2

63.3

0.00

2.5

8.3

30.0

21.7

6.7

86.7

6.7

0.00
57

63

10

110

102

12

0

6

67

42

11

0

0

52

68
47.5

52.5

8.3

91.7

85.0

10.0

0.00

5.0

55.8

35.0

9.2

0.00

0.00

43.3

56.7

Table 2: Frequency and percentage distribution of demographic variables as per education of parents, occupation of parents, stream of education and percentage of marks in $10^{\text {th }}$ final exam.

$\mathbf{N}=\mathbf{2 4 0}$

Sl.

No. Demographic variables

\begin{tabular}{cccc}
\multicolumn{2}{c}{ Rural } & \multicolumn{2}{c}{ Urban } \\
\hline Frequency & Percentage & Frequency & Percentage \\
$(\mathbf{f})$ & $(\%)$ & $(\mathbf{f})$ & $(\%)$
\end{tabular}

1. Education of father
a. Illiterate
b. Primary school
c. Secondary school
d. PUC
e. Degree/professional
f. Post graduation \& above

(f)

(\%)

(f)

(\%)

2. Education of mother
a. Illiterate
b. Primary school
c. Secondary school
d. PUC
e. Degree/Professional
f. Post graduation \& above

$\begin{array}{cc}0.8 & \\ 0.0 & \\ 1.7 & \\ 93.3 & 0 \\ 0.0 & 75 \\ 4.2 & 45\end{array}$

0.0

0.0

0

2

112

0

5

0.0

0.0

33.3

63.3

0

0

0.0

0.0

62.5

75

37.5

3. Occupation of father
a. Government employee
b. Private employee
c. Daily wages
d. Business

0
0
40
76
4
0

4. Occupation of mother
a. Private employee
b. Government employee
c. Homemaker
d. Daily wages
e. Self employed

5. Streams of your education
a. Science

40

33.3

0.0

69.2 

b. Commerce

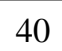
40
c. Arts

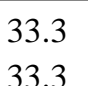
40
33.3
33.3
40

6. Percentage of marks in 10 final exam
a. $<35 \%$
b. $36-60 \%$
c. $>60 \%$

0
28
92

0.0

38.3

61.7

Analysis of Overall Level of Self-esteem of adolescents of Rural and Urban Pre university Colleges Table 3: Frequency and Percentage Distribution of Overall Level of Self-esteem of Rural and Urban Preuniversity Colleges

\begin{tabular}{lccccc}
\hline & & \multicolumn{2}{c}{$\mathbf{N = 2 4 0}$} \\
\cline { 3 - 6 } Sl. & $\begin{array}{c}\text { Level of self- } \\
\text { Noteem }\end{array}$ & $\begin{array}{c}\text { Frequency } \\
(\mathbf{f})\end{array}$ & $\begin{array}{c}\text { Percentage } \\
(\boldsymbol{\%})\end{array}$ & $\begin{array}{c}\text { Frequ ency } \\
(\mathbf{f})\end{array}$ & $\begin{array}{c}\text { Percentage } \\
(\boldsymbol{\%})\end{array}$ \\
\hline 1 & & 4 & 3.30 & 118 & 98.30 \\
2 & High & 104 & 86.70 & 1 & 0.83 \\
3 & Average & 12 & 10.00 & 1 & 0.83 \\
\hline
\end{tabular}

Majority (98.3\%) of adolescents in Urban Preuniversity College had high level of Self-esteem, whereas the adolescents of rural Pre-university College majority $(86.7 \%$ ) had average level of Self-esteem. $10 \%$ of the subjects in rural Preuniversity College had low level of Self-esteem. similar percentage $(0.83 \%)$ of adolescents in urban Pre-university College had average and low level of self-esteem. Very minimal percentage $3.3 \%$ of subjects had high level of Self-esteem among adolescents of rural Preuniversity College.

\section{Analysis of Overall Level of Achievement Motivation of adolescents of Rural and Urban Pre- university Colleges}

Table 4: Frequency and Percentage Distribution of Overall Level Achievement Motivation of Rural and Urban Pre-university College

\begin{tabular}{lccccc}
\hline & & & & $\mathbf{N}=\mathbf{2 4 0}$ \\
Sl. & achievement & Rural & \multicolumn{2}{c}{ Urban } \\
No & motivation & $(\mathbf{f})$ & $\begin{array}{c}\text { Prequency } \\
(\mathbf{f})\end{array}$ & $\begin{array}{c}\text { Percentage } \\
(\boldsymbol{\%})\end{array}$ \\
\hline 1 & Low & 4 & 3.3 & 4 & 3.3 \\
2 & Below average & 40 & 33.3 & 8 & 6.7 \\
3 & Average & 10 & 8.3 & 8 & 6.7 \\
4 & Above average & 60 & 50.0 & 16 & 13.3 \\
5 & High & 6 & 5.0 & 84 & 70.0 \\
\hline
\end{tabular}

Most (70\%) of the adolescents of urban preuniversity college had high level of achievement motivation whereas $50 \%$ of them from rural preuniversity college had above average level of achievement motivation. $33.3 \%$ of subjects in rural pre-university college had below average level of achievement motivation. $8.3 \%$ and $6.7 \%$ of subjects in rural and urban pre-university college had average level of achievement motivation. Very few (5\%) subjects had high level of achievement motivation in rural pre- university college. Similar percentage (3. 3\%) in both rural and urban pre-university college had low level of achievement motivation. 
Comparison of level of Self-esteem among Adolescents of Rural and Urban Pre-university Colleges

Table 5: Mean and t value of Level of Self-esteem

\begin{tabular}{lccccc}
\hline & Mean & $\begin{array}{c}\text { Standard } \\
\text { deviation }\end{array}$ & $\begin{array}{c}\text { Mean } \\
\text { difference }\end{array}$ & t value & P value \\
\hline Rural & 21.66 & 2.006 & 4.22 & $15.892^{*}$ & $\mathrm{p}<0.05$ \\
Urban & 25.88 & 2.111 & * Significant
\end{tabular}

The calculated ' $\mathrm{t}$ ' value $(\mathrm{t}=15.892)$ was higher than the table value 1.98 , at 0.05 level of significance, hence there was significant difference in self-esteem among adolescents of Rural and Urban Pre-university College.

Comparison of Level of Achievement Motivation among Adolescents of Rural and Urban Preuniversity Colleges

Table 6: Mean and t value of level of Achievement Motivation

\begin{tabular}{|c|c|c|c|c|c|}
\hline & & & & & $\mathrm{N}=\mathbf{2 4 0}$ \\
\hline & Mean & $\begin{array}{l}\text { Standard } \\
\text { deviation }\end{array}$ & $\begin{array}{r}\text { Mean } \\
\text { difference }\end{array}$ & $t$ value & $P$ value \\
\hline Rural & 34.86 & 2.663 & & & \\
\hline Urban & 40.23 & 2.343 & 0.34 & $10.498^{\circ}$ & $p<0.00$ \\
\hline
\end{tabular}

The calculated' $t$ ' value $(t=16.498)$ was higher than the table value (1.98) at 0.05 level of significance, indicates significant difference in level of Achievement Motivation among adolescents of Rural and Urban Pre-university College.

Association of level of self-esteem among adolescents of rural and urban Pre-university Colleges with selected demographic variables

Table 7: Association between the level of self-esteem of adolescents in rural and urban Pre-university College with selected demographic variables

$$
\mathbf{N}=\mathbf{2 4 0}
$$

\begin{tabular}{|c|c|c|c|c|c|c|c|}
\hline \multirow[b]{2}{*}{ No } & \multirow[b]{2}{*}{ Demographic variables } & \multicolumn{3}{|c|}{ Rural } & \multicolumn{3}{|c|}{ Urban } \\
\hline & & $\chi^{2}$ & $\mathbf{p}$ & df & $\chi^{2}$ & $\mathbf{P}$ & df \\
\hline 1 & Age in years & 1.124 & .289 & 1 & .075 & .785 & 1 \\
\hline 2 & Religion & 0.234 & .890 & 2 & 3.887 & .143 & 2 \\
\hline 3 & Gender & 1.109 & .292 & 1 & .653 & .419 & 1 \\
\hline 4 & Residential area & 1.725 & .189 & 1 & 1.282 & .258 & 1 \\
\hline 5 & Type of family & .862 & .353 & 1 & .474 & .491 & 1 \\
\hline 6 & Order of birth & .069 & .966 & 2 & 1.681 & .432 & 2 \\
\hline 7 & Monthly income & 0.000 & 1.000 & 1 & 0.000 & 1.000 & 1 \\
\hline 8 & Education of father & .000 & 1.000 & 1 & 2.717 & .213 & 1 \\
\hline 9 & Education of mother & .075 & .785 & 1 & $5.347^{*}$ & .021 & 1 \\
\hline 10 & Occupation of father & 1.142 & .285 & 1 & .260 & .796 & 1 \\
\hline 11 & Occupation of mother & 1.725 & .189 & 1 & .000 & 1.000 & 1 \\
\hline 12 & Streams your education & $6.150 *$ & .046 & 2 & $5.094^{*}$ & .024 & 1 \\
\hline 13 & Percentage of marks in $10^{\text {th }}$ exam & .025 & .873 & 1 & $8.689 *$ & .003 & 1 \\
\hline
\end{tabular}


Association of level of Achievement Motivation among adolescents of Rural and Urban Pre-university College with selected demographic variables

Table 8: Association between the level of achievement motivation of adolescents in rural and urban Pre-university College with selected demographic variables

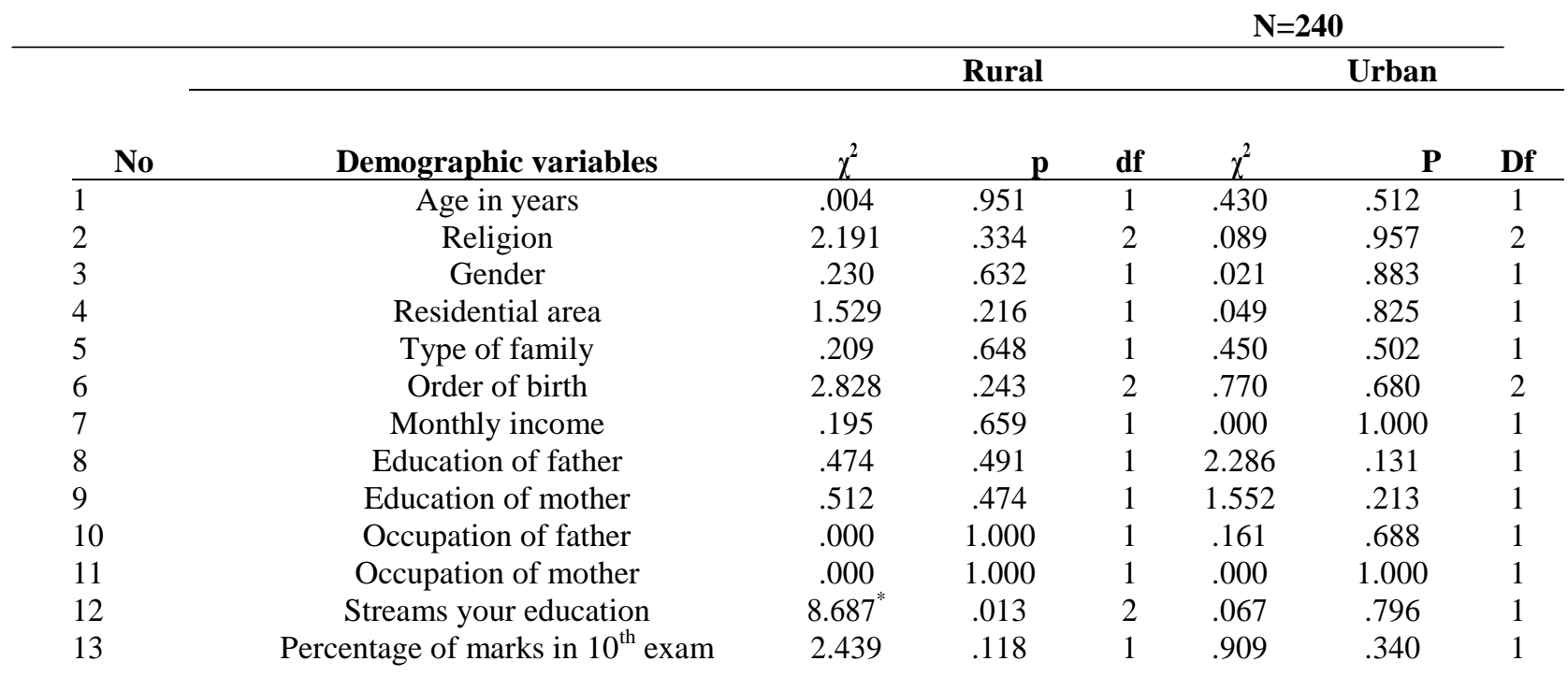

Table value: $\chi^{2}=3.84, \mathrm{p}<0.05$

\section{Discussion}

The present study revealed that majority $(98.3 \%)$ of adolescents in urban pre-university college had high level of self-esteem, whereas the adolescents of rural pre-university college majority $(86.7 \%)$ had average level of Self-esteem. 10\% of the subjects in rural pre-university college had low level of Self-esteem. Very minimal percentage $3.3 \%$ of subjects had high level of self-esteem in the rural pre-university college.

The study findings are supported by a comparative study that was conducted to assess self-esteem among rural and urban pre-university college adolescents in Kashmir, which revealed that majority $82.3 \%$ of adolescents in Urban Preuniversity College had high level of Self-esteem whereas $11.5 \%$ of adolescents in Rural Preuniversity College had low level Self-esteem. Only $6.2 \%$ of adolescents had high self- esteem in Rural Pre-university College. ${ }^{9}$

The present study revealed that most $70 \%$ of the adolescents of Urban pre-university College had high level of achievement motivation whereas $50 \%$ of them from rural Pre-university College had above average level of achievement motivation. Very few percentage $5 \%$ of subjects
* Significant

had high level of achievement motivation in rural Pre-university College. Similar percentage (3.3\%) in both rural and urban Pre-university College had low level of achievement motivation.

The study findings are supported by a comparative study that was conducted to assess the level of achievement motivation among rural and urban students of Pre-university College in Sikkim state. Results revealed that $80 \%$ of the adolescents of Urban Pre-university College had high level of Achievement motivation whereas $60 \%$ of the adolescents from rural Pre-university College had average level of achievement motivation. Only $5 \%$ of subjects in both rural and urban Pre-university College had low level of Achievement motivation. ${ }^{10}$

The investigator found that there was a significant difference in the level of self-esteem of adolescents rural and urban Pre-university College $(\mathrm{t}=15.892, \mathrm{p}<0.05)$.

The findings of the study are similar to comparative study conducted on level of selfesteem among adolescents in rural and urban Preuniversity College of Agra. Result showed that majority of adolescents from urban Pre-university College had high level of Self-esteem compared 
to rural Pre-university College $(\mathrm{t}=4.85$ and $\mathrm{t}=2.39$, $\mathrm{p}<0.05){ }^{11}$

The investigator found that there was a significant difference in the level of achievement motivation of adolescents of rural and urban Pre-university College $(t=16.498, \mathrm{p}<0.05)$.

The findings of the study are similar to comparative study conducted on level of achievement motivation among adolescents in rural and urban Pre-university College of Kashmir. Results revealed that majority of adolescents from urban Pre- University College had high level of achievement motivation compared to rural Pre- university College. $(\mathrm{t}=3.84$ and $\mathrm{t}=2.34, \mathrm{p}<0.05) .^{12}$

The investigator found that there was significant association between level of Self-esteem of Rural and Urban adolescents studying in Pre-university College with streams of education. The data also shows significant association between level of self-esteem of urban adolescents studying in Preuniversity College with education of mother and percentage of marks in $10^{\text {th }}$ exam.

The findings of the study are similar to comparative study conducted on influence of parent's education on self-esteem of adolescents. A total of 200 intermediate students of XI and XII belonging to parents having four levels of education (intermediate, high school, graduation and post graduation) were administered Rosenberg Self-esteem Scale studying in Varanasi district. Participants belonged to three streams science, arts and commerce. Results showed that the mean scores of Self-esteem of adolescents found to be 127.34, 121.8, 120.28, and 114.94 for post graduate, graduate, intermediate, and high school educated mothers. The comparison of mean scores made clear that levels of scores made clear that levels of mothers' education have an positive effect on achievement motivation in academic area. Higher level of mother's education leads to higher level of Self-esteem in academic area but not in other areas $[\mathrm{F}=9.97, \mathrm{p}<0.001] .{ }^{13}$

The investigator found that there was significant association between level of achievement motivation among adolescents of rural Preuniversity College with streams of education.

The findings of present study are similar to descriptive study to investigate the gender related differences and differences across academic majors on achievement motivation among college students in Jammu. Result revealed the significant difference between the achievement motivation of Sciences and arts stream students and achievement motivation among male and female college students [mean and SD of science students $=140.82$ and 3.69, mean and SD of arts students $=128.93$ and 3.08 respectively]. ${ }^{14}$

\section{Conclusion}

Self-esteem and achievement motivation is a prerequisite for academic success. Health care professionals have a responsibility to be informed about the importance of development of selfesteem and achievement motivation in adolescents. Health care educators should ensure that students are provided with a curriculum that offers the opportunity to increase student's understanding of the need for self-esteem and achievement motivation. When those students become health care professionals, they will be able to provide support and information to families when the situation arises.

\section{References}

1. Gupta S. The short textbook of paediatrics. $10^{\text {th }}$ ed. New Delhi: Jaypee Brothers Medical Publishers; 2004. p. 55-7.

2. India has largest adolescent population in the world. [online]. 2011 Feba 26. Available from: URL: http://www.hindustantimes.com

3. Hurlock EB. Developmental psychology. A lifespan approach. $5^{\text {th }}$ ed. Philadelphia: McGraw Hill; 2005.

4. WHO Partners in life skills education. Conclusions from a United Nations Interagency Meeting. Geneva: World Health Organisation; 2001. 
5. Rajani R. UNICEF. The participation rights of adolescents: a strategic approach. Commissioned paper for UNICEF. [online]. Available from: URL: http://www.unicef.org/brogramme/youthday/assets/participation.pdf

6. Perkins DF. Developmental psychology milestones ages 13 to 18 . [online]. Available from: URL: http://www.education.com

7. National report on state of self-esteem. [online]. Available from: URl:http://www.the-state-of-selfesteem.shop/com/self-esteemstatistics.html

8. Sarfaraz A, Sinha R, Nigam. The effect of motivation on academic achievement of aided and private pre-university college students. Indian Journal of Psychometry and Education 2008;39(2):164-8.

9. Vijayalaxmi N, Natesan V. Factors affecting self-esteem and academic achievement - a comparative study of government and private school students. Indian Psychology Review;36(2):1-7.

10. http://dx.doi.org/10.1016/j.achievementmotivation.2006.05.016

11. McLaren JE, CohenLL. A comparison of self-esteem for adolescents in rural and urban pre-university colleges. J Paediatr Psychol 2005;30(5):387-96.

12. McCaul KD, Malott JM. A comparison of achievement motivation and academic achievement in government and private college. Psychol Bull 1984;95:516-33.

13. Neha A, Shobhna J. Influence of parents' education on achievement motivation of adolescents. Indian Journal of Scientific Research 2009 Mar;6:72-9.

14. Chandra S. Achievement motivation across gender and different academic majors. Journal of Educational and Developmental Psychology 2012 Mar; 2(2):75-6. 